Abstracta Iranica

Revue bibliographique pour le domaine irano-aryen

Volume 29 | 2008

Comptes rendus des publications de 2006

\title{
Les apocryphes syriaques. Paris, 2005. (Études syriaques, 2)
}

\section{Rédaction}

\section{OpenEdition}

1 Journals

\section{Édition électronique}

URL : http://journals.openedition.org/abstractairanica/29822

DOI : 10.4000/abstractairanica.29822

ISSN : 1961-960X

Éditeur :

CNRS (UMR 7528 Mondes iraniens et indiens), Éditions de l'IFRI

\section{Édition imprimée}

Date de publication : 15 mai 2008

ISSN : 0240-8910

\section{Référence électronique}

Rédaction, «Les apocryphes syriaques. Paris, 2005. (Études syriaques, 2) », Abstracta Iranica [En ligne], Volume 29 | 2008, document 267, mis en ligne le 15 septembre 2008, consulté le 26 septembre 2020 URL : http://journals.openedition.org/abstractairanica/29822 ; DOI : https://doi.org/10.4000/ abstractairanica.29822

Ce document a été généré automatiquement le 26 septembre 2020.

Tous droits réservés 


\section{Les apocryphes syriaques. Paris, 2005. (Études syriaques, 2)}

\section{Rédaction}

Ce second ouvrage de la série développe les principales thématiques liées aux apocryphes syriaques : Jésus et sa parenté, épopées d'apôtres partis évangéliser le monde connu, histoires de disciples fondateurs de communautés en Orient, interprétations et exégèses bibliques, récits pseudépigraphes, apocalypses, littérature juridique... Très vite, ces textes syriaques ont été transmis dans d'autres aires culturelles, en particulier en arménien, en géorgien et en arabe, où ils ont formé le socle des traditions relatives aux origines chrétiennes. Les chapitres constituent autant d'introductions, par des spécialistes de ces questions, aux différents genres présentés.

\section{INDEX}

Thèmes : 6.3. Autres religions

\section{AUTEURS}

\section{RÉDACTION}

Directeur de la revue et secrétariats (Paris et Téhéran) 